\title{
An 850 year record of climate and fluctuations of the iceberg- calving Nellie Juan Glacier, south central Alaska, U.S.A.
}

\author{
David J. BARGLAY, ${ }^{1}$ Gregory C. WILES, ${ }^{2}$ Parker E. CALKiN ${ }^{3}$ \\ ${ }^{1}$ Department of Geology, State University of New York College at Cortland, Cortland, NY 13045, U.S.A. \\ E-mail: barclayd@cortland.edu \\ ${ }^{2}$ Department of Geology, The College of Wooster, Wooster, OH 44691, U.S.A. \\ ${ }^{3}$ Institute of Arctic and Alpine Research, University of Colorado CB-450, Boulder, CO 80309-0450, U.S.A.
}

\begin{abstract}
Tree-ring cross-dates of 46 glacially killed trees show that the tidewater Nellie Juan Glacier, Alaska, advanced seaward during the 16 th and 17 th centuries AD. Icescarred trees at the late-Holocene end moraine indicate that the terminus was at its recent maximum from 1842 to 1893 . Historical observations and photographs show that subsequent slow retreat changed to rapid iceberg-calving retreat after 1935, and that the tidewater terminus had withdrawn about $3.3 \mathrm{~km}$ from the late-Holocene maximum by 1992 . Comparison with paleoclimate records from nearby land-terminating glaciers and an 850 year tree-ring-width chronology indicates that the timing of the 19 th-century maximum stand of Nellie Juan Glacier was controlled by changes in summer temperature and radiation. However, rapid iceberg-calving retreat did not begin until 40 years of slow retreat had brought the tidewater terminus back from the terminal moraine shoal. Therefore, both the dimensions of the terminal moraine shoal and the magnitude and duration of climate change were important in initiating rapid retreat of this tidewater glacier system.
\end{abstract}

\section{INTRODUCTION}

Alaskan tidewater glaciers are known to undergo cycles of slow advance followed by rapid retreat (Post, 1975; Post and Motyka, 1995). During much of this cycle the position of the terminus is relatively insensitive to climate, depending instead on characteristics of ice flow, subglacial water and sediment systems, and geometry of the fjord around the terminus (Mercer, 1961; Brown and others, 1982; Meier and Post, 1987; Powell, 1991; Van der Veen, 1996). However, analyses of glacier histories and paleoglacier area-altitude relationships in Lituya Bay (Mann, 1986) and in the Kenai Fjords (Wiles and others, 1995), Alaska, have suggested that some tidewater systems are sensitive to climate when at an extended position following a major advance.

In this paper, we consider the role of climate in forcing late-Holocene fluctuations of Nellie Juan Glacier in south central Alaska. We use high-precision tree-ring methods to simultaneously reconstruct the history of Nellie Juan Glacier and develop a new tree-ring record of paleoclimate for the region. The Nellie Juan history is then compared with both the new tree-ring record and an updated regional history of land-terminating glaciers to assess the influence of climate on late-Holocene fluctuations of this tidewater glacier system.

\section{Setting}

Nellie Juan Glacier is located on the western side of Prince William Sound in south central Alaska. At present, ice descends steeply from the northern Sargent Ice Field to terminate as an iceberg-calving cliff in a narrow fjord (Fig. 1). However, observations in 1887 (Davidson, 1904) together with vegetative and geomorphic evidence indicate that Nellie Juan Glacier formerly extended to the southwestern shore of
Derickson Bay. A spit dividing Nellie Juan lagoon from Derickson Bay is the wave-eroded remnant of a terminal moraine shoal formed at this late-Holocene-maximum stand. During this maximum, ice also expanded southeast from Nellie Juan lagoon over a broad rocky lowland towards a small adjacent glacier. Although the two termini merged during the late-Holocene maximum (Fig. 1), the smaller ice tongue never extended sufficiently to become a significant source of ice to the Nellie Juan terminal lobe.

The study area lies at the head of one of many fjords cut into the northern Kenai Mountains during the Pleistocene. Peaks around Nellie Juan lagoon attain elevations of 500$850 \mathrm{~m}$, while several massifs in the accumulation area reach $>1300 \mathrm{~m}$. Climate of the region is maritime, with the nearest climate station at Seward, $67 \mathrm{~km}$ to the southwest, recording mean temperatures of $-4.2^{\circ} \mathrm{C}$ in January, $13.2^{\circ} \mathrm{C}$ in July and mean annual precipitation of $1688 \mathrm{~mm}$ for the period 1908-90 (personal communication from Alaska Climate Research Center, 2002). The firn line of Nellie Juan Glacier is at about $475 \mathrm{~m}$, based on aerial photographs taken in early September 1972 and 1986. Using this firn line and the 1992 terminus position gives an accumulation-area ratio for this system of 0.88 .

\section{LATE-HOLOGENE ADVANCE AND RETREAT OF NELLIE JUAN GLACIER}

Glacial geologic mapping and tree-ring sampling of icescarred and glacially killed trees were completed in June 1992 and July 2000. We describe below the key sites and methods used to reconstruct the late-Holocene history of Nellie Juan Glacier. 


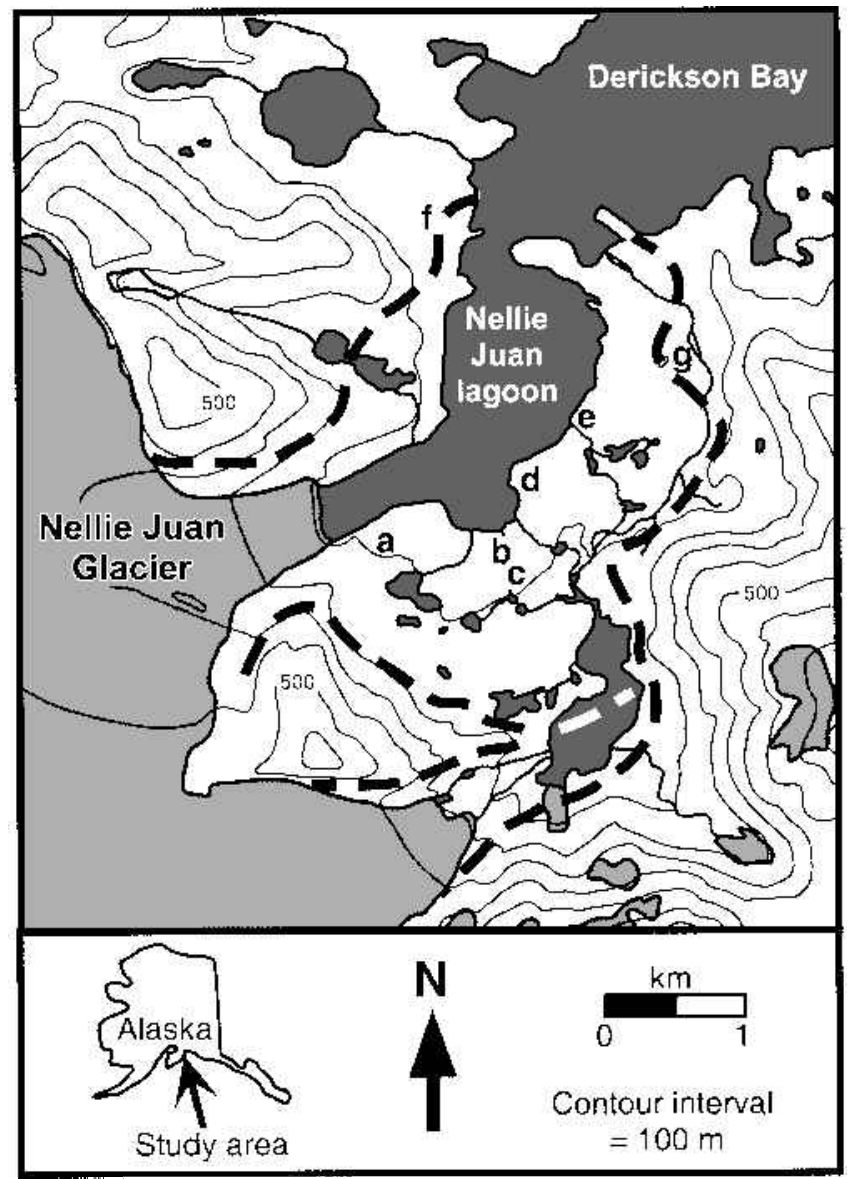

Fig. 1. Forefield of Nellie Juan Glacier in south central Alaska. Dark shade is water; light shade is ice. The dashed lines indicate late-Holocene glacier margins. Letters $a-f$ are sample sites discussed in the text and in Table 1. Based on U.S. Geological Survey Seward (B-4) quadrangle, 1: 63360 series, 1950 (revised 1994).

\section{Tree-ring cross-dates of ice-margin advance}

A snowmelt stream on the southern shore of Nellie Juan lagoon has eroded a gully through a terrace of ice-contact glacial sediments since deglaciation of the area in 1972 (site b, Fig. 1). Exposed within the walls of the gully and in the stream bed are many subfossil logs of mountain hemlock (Tsuga mertensiana). Some remain in growth position, while others, including some over $10 \mathrm{~m}$ long and $1 \mathrm{~m}$ in diameter, are tipped over and pushed together into piles. Additional logs have been transported out of the gully and lie scattered across a fan delta that has prograded into Nellie Juan lagoon.

One to six cores or a disk were taken from each of 32 moderately to well-preserved logs. Samples were taken from close to the base of each log to maximize the number of growth rings collected, although rot and abrasion sometimes required sampling of less favorable points of the trunk. One or two cores were also taken from as high as possible on the largest and best-preserved logs to allow identification of pinch-out rings that are less prevalent towards the crown of the tree. Each log was examined to find bark, and, if located, an additional core was taken to ensure that the last years of growth were sampled.

In the laboratory, annual ring widths were measured to the nearest $0.001 \mathrm{~mm}$ and processed using standard dendrochronological techniques (Cook and Kairiukstis, 1990). The subfossil ring-width time series were cross-dated with series
Table 1. First and last years of growth of glacially killed trees at Nellie Juan Glacier

\begin{tabular}{|c|c|c|}
\hline \multicolumn{3}{|c|}{ Site a - On slopes overlooking inner fjord: } \\
\hline $1092-1519^{3}$ & $1232-1539^{2}$ & $1266-1515^{3}$ \\
\hline $\begin{array}{l}1068-1592^{2} \\
1340-1596^{2} \\
1171-1587^{1,3} \\
1402-1590 \\
1222-1568^{3} \\
1094-1592\end{array}$ & $\begin{array}{r}\text { Site } b-\text { Buried in glac } \\
1439-1596^{1} \\
1431-1593 \\
1099-1595^{2} \\
1144-1593 \\
1090-1593 \\
1402-1582^{3}\end{array}$ & $\begin{array}{l}\text { gully: } \\
1238-1596 \\
1314-1595 \\
1071-1595 \\
1294-1591 \\
1428-1593\end{array}$ \\
\hline $\begin{array}{l}1214-1591 \\
1284-1582^{3} \\
1399-1599 \\
1500-1594 \\
1314-1592\end{array}$ & $\begin{array}{r}\text { Site } b-\text { Fan delta surfac } \\
1437-1598 \\
1281-1544^{3} \\
1420-1595 \\
1403-1594 \\
1376-1596\end{array}$ & $\begin{array}{l}\text { of gully: } \\
1366-1596 \\
1264-1548^{3} \\
1361-1592 \\
1461-1578^{3} \\
1312-1562^{3}\end{array}$ \\
\hline $\begin{array}{l}1373-1595 \\
1176-1413^{3}\end{array}$ & $\begin{array}{r}\text { Site c - In shallow strean } \\
1187-1310^{3} \\
1244-1599\end{array}$ & $\begin{array}{l}\text { ve gully: } \\
\qquad 1425-1610^{2}\end{array}$ \\
\hline $1034-1598$ & \multicolumn{2}{|c|}{$\begin{array}{l}\text { Site } d-\text { Northeast of main sampling gully: } \\
\quad 1212-1581^{3}\end{array}$} \\
\hline \multicolumn{3}{|c|}{ Site e - In waterfall at lagoon shore: } \\
\hline
\end{tabular}

$1296-1642$

In intertidal sediments $300 \mathrm{~m}$ northeast of site e:

${ }^{1}$ Stump in growth position.

${ }^{2}$ Outermost ring preserved.

${ }^{3}$ Badly rotted or abraded outer rings.

from living mountain hemlock growing on the southwest shore of Derickson Bay (site f, Fig. 1) using the COFECHA computer program (Holmes, 1983). All cross-dates were visually confirmed using marker rings.

The first years of growth of subfossil logs from the gully (Table 1) show that forest was established at this site, and thus Nellie Juan Glacier withdrew up-fjord, from at least the mid-11th century AD. The last dates of tree growth are concentrated between 1592 and 1596. This clustering, together with the burial of the logs in ice-contact deposits, indicates that the margin of Nellie Juan Glacier advanced over and killed the forest at this site during these years.

Many of the additional 14 subfossil logs (Table 1; Fig. 1) sampled from the southern and eastern margins of Nellie Juan lagoon were from stumps still in growth position or logs buried in glacial deposits that we assume were close to their original growth location. The last cross-dated years of growth from each of these sites clearly show a spatial sequence with progressively later kill dates occurring closer to Derickson Bay. These results show that Nellie Juan Glacier advanced seaward from the mid-16th through the early 17 th century AD, with ice also expanding laterally over the lowland southeast of Nellie Juan lagoon.

\section{Tree-ring dates of the late-Holocene-maximum stand}

The late-Holocene-maximum stand of Nellie Juan Glacier is marked by a fairly continuous ring of erosional and vegetative trimlines and ice-marginal deposits around the forefield (Fig. 1). The oldest living trees found just beyond this ice-margin position (sites f and g, Fig. 1) germinated in the $\mathrm{AD} 1320 \mathrm{~s}$, indicating that this maximum was the most 


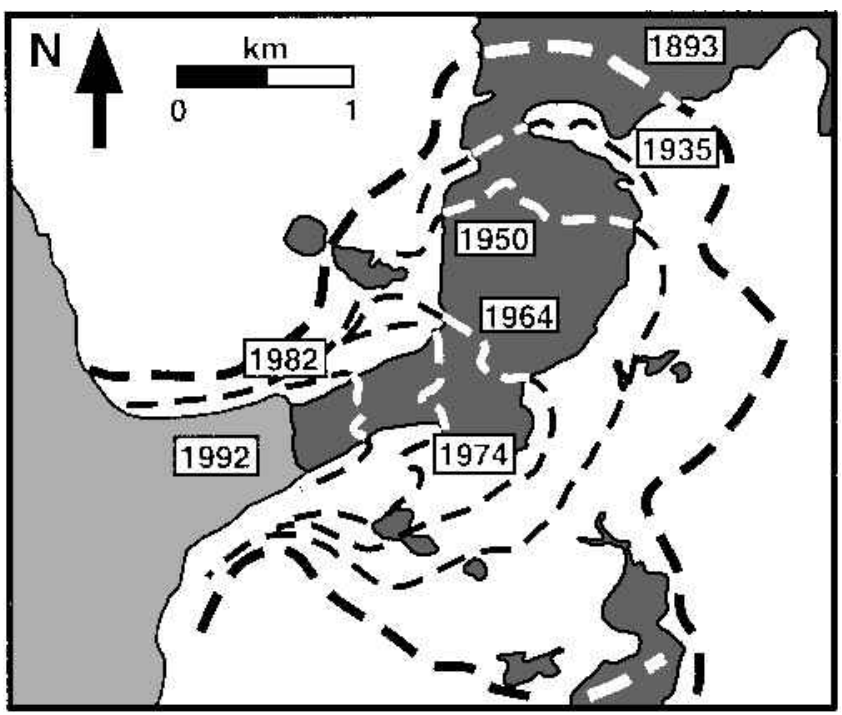

Fig. 2. Retreat of Nellie Juan Glacier during the 20th century. Dark shade is water; light shade is ice. Ice-marginal positions taken from vertical aerial photographs provided by A. Post, and from oblique photographs in Field (1937).

extensive stand of Nellie Juan Glacier in at least the last 670 years. The construction date of the terminal moraine is inferred from ice-scarred trees growing on a prominent bedrock knob at site f. One tree partially buried in the outermost ridge of the terminal moraine germinated in 1720 and suffered severe trauma from the partial burial from 1877 to 1884. Viereck (1967) described two other trees nearby that were similarly damaged in 1863 and 1880.

Ages of living trees growing on the terminal moraine at site $\mathrm{f}$ were used to determine when ice began to retreat. Multiple cores were taken from the base of each trunk to ensure sampling of the innermost rings, and then 15 years were subtracted from the innermost-ring date to account for the time elapsed between availability of the moraine for growth due to ice retreat and germination of seedlings. This ecesis time of 15 years was based on studies by Viereck (1967) and Wiles and others (1999) around Prince William Sound and the northern Kenai Mountains. The oldest trees at site f (Fig. 1) indicate stabilization of the outer moraine ridges in 1842 and the inner ridges in 1893.

Taken together, the ice-scarring and moraine-stabilization results suggest that Nellie Juan Glacier reached its maximum position in the 1840s. Ice then stayed at or near this location until retreat began in the 1890s. These results are consistent with the earliest map of glaciers in the area by S. Applegate, who depicted Nellie Juan Glacier in 1887 as forming the westernmost edge of Derickson Bay (Davidson, 1904).

\section{Photographic record of 20th-century retreat}

In 1908 and 1910 a bare zone $140 \mathrm{~m}$ wide separated the terminal moraine on a bedrock knob (our site f) from ice on the southwest side of Derickson Bay (Grant and Higgins, 1913; Tarr and Martin, 1914). The central portion of the terminus across Derickson Bay was grounded on a gravel beach that in places was only flooded at high tide, this beach being the top of the terminal moraine shoal of Nellie Juan Glacier. Photographs show the terminus having a fairly gentle gradient with moderate crevassing, and ending as a small cliff from which icebergs up to a few meters in length were dis- charged. The general appearance of the terminus was little changed in 1925 and 1935, although the tidewater margin had retreated 470-580 $\mathrm{m}$ since 1910 (Field, 1937).

Aerial photographs from the 1950 s to 1980 s show a dramatic change in the recession style of Nellie Juan Glacier. By 1950 the tidewater terminus facing Derickson Bay had retreated from the terminal moraine shoal and steepened into $1.1 \mathrm{~km}$ wide iceberg-calving cliff (Fig. 2). During the 1960s and 1970s, calving embayments developed and icebergs over $50 \mathrm{~m}$ in length were discharged into Nellie Juan lagoon. In the 1980s the terminus straightened into a $400 \mathrm{~m}$ wide ice cliff in the narrow fjord west-southwest of the lagoon (Fig. 2), and by 1992 the terminus had retreated $2250 \mathrm{~m}$ from the 1950 position.

\section{Synthesis of late-Holocene advance and retreat}

Tree-germination dates from as early as AD1034 (Table 1) from the lagoon shore show that the recent advance of Nellie Juan Glacier was the most extensive of this system during the past 1000 years. Trees were being killed by the advancing ice margin from 1539 to 1642; the distance separating these kill dates along the lagoon shore suggests that the tidewater terminus was advancing at about $30 \mathrm{~m} \mathrm{a}^{-1}$ during this interval. Although this estimate is relatively crude due to the differing elevations of the samples and their peripheral locations relative to the tidewater terminus, it is reasonable when compared with advance rates of other Alaskan tidewater glaciers (Meier and Post, 1987).

The glacial history between 1642 and 1842, when no treering dates are available, is uncertain. Assuming that the terminus continued to advance at $30 \mathrm{~m} \mathrm{a}^{-1}$ after killing the trees at site e (Fig. 1), the tidewater margin would have been close to the present position of the lagoon-mouth spit by 1642, when the last cross-dated tree was killed (Table 1). It is probable that climatic warming in the $1680 \mathrm{~s}-1780 \mathrm{~s}$ (see next section) caused some terminus recession, but it is unlikely that rapid iceberg-calving retreat was initiated. Had rapid retreat occurred, the terminus would have calved back to near its present position at the head of the fjord before stabilizing and building a new protective terminal shoal. There is simply too little time to do this and readvance to the late-Holocene maximum by 1842, so we suggest that Nellie Juan Glacier remained in a moderately expanded position from the mid17 th century until the push to the late-Holocene maximum.

Retreat of the terminal lobe during the 1890s-1930s was slow and dominated by surface melting and backwasting of the margins. However, once the tidewater terminus retreated from the terminal moraine shoal, iceberg calving became more important for the northern edge of the terminal lobe, and the retreat rate accelerated. From 1950 to 1992 the iceberg-calving cliff retreated at an average of $55 \mathrm{~m} \mathrm{a}^{-1}$. Although double the retreat rate of the land-based southern edge of the terminal lobe, this retreat rate of the tidewater terminus was an order of magnitude slower than retreat rates of other Alaskan tidewater glaciers (Meier and Post, 1987). This may reflect a low calving rate caused by shallow water depths in Nellie Juan lagoon, the bathymetry of which is unknown, or perhaps a high ice flux to the terminus offsetting calving losses. Alternatively, the restricted circulation of the lagoon may make the dynamics of Nellie Juan Glacier transitional to the behavior of lake-calving glaciers; such glaciers in West Greenland having been noted as more mechanically stable and thus less active than tidewater termini (Warren, 1991). 


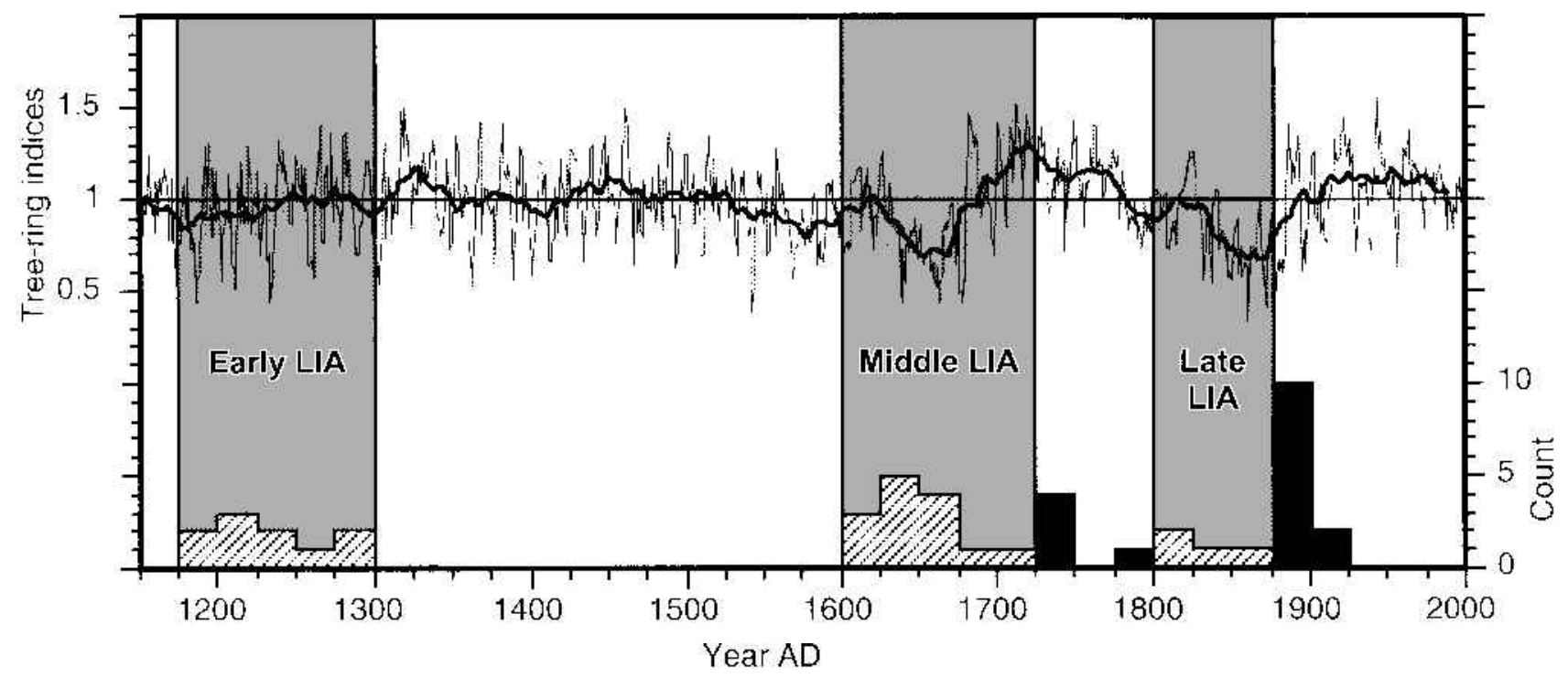

Fig. 3. Paleoclimate records for past 850 years in south central Alaska. Upper panel shows annual ring widths for the Nellie fuan long chronology together with a 25 year mean. Lower panel is a composite history of 12 land-terminating glaciers in south central Alaska. Striped bars are number of advancing glaciers per 25 year interval; solid bars are the number of major moraines dated to each 25 year interval.

\section{PALEOGLIMATE DATA}

Two sources of paleoclimate data are used to assess climatic controls on the late-Holocene advance and retreat of Nellie Juan Glacier. The first is a composite history from nine land-terminating glaciers in western Prince William Sound (Wiles and others, 1999) supplemented with new data from Scott, Sheridan and Sherman Glaciers near Cordova, $150 \mathrm{~km}$ east of Nellie Juan. This record shows the same integrated response to changes in accumulation and ablation as experienced by Nellie Juan Glacier, but without the effects of the iceberg-calving margin, and is based entirely on cross-dates of glacially killed trees and tree-ring minimum ages of moraines.

The regional glacial record (Fig. 3) shows three major expansions in the past 850 years. An early-"Little Ice Age" (LIA) advance brought four termini into forests between $\sim 1180$ and 1300. Trees killed by this advance are found up-valley close to modern ice margins, whereas trees killed

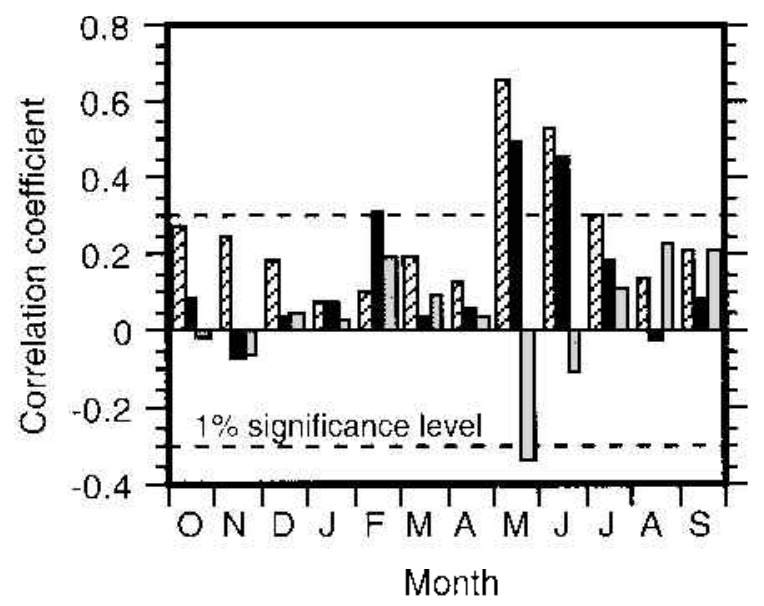

Fig. 4. Correlation between Nellie Fuan long tree-ring-width chronology and monthly climate data for Seward, 1908-90. Striped bars are monthly temperature range (maximum minus minimum), black bars are mean monthly temperature, and gray bars are total monthly precipitation. by seven glaciers between $\sim 1600$ and 1715 in the middle LIA are significantly farther down-valley. The earliest interval of moraine stabilization occurs immediately after the middleLIA advance, suggesting that these moraines mark the limit of these ice expansions. A late-LIA advance is recorded by trees killed between 1800 and the 1850s, and large moraines constructed by all 12 glaciers between 1874 and 1918 .

The second paleoclimate dataset used for this comparison is a tree-ring-width chronology developed from living and subfossil trees at Nellie Juan Glacier. This is a continuous annually resolved record of climate spanning the past 850 years that can help identify intervals of climate favorable for glacier advance or retreat. This tree-ring chronology is a significant update to a previous chronology by Barclay and others (1999), so its development is detailed below.

\section{Development of Nellie Juan long tree-ring-width chronology}

The Nellie Juan long chronology was developed using two ring-width series from each of 19 subfossil trees from the Nellie Juan forefield, 14 living trees at site f (Fig. 1) and 3 subfossil trees from the forefield of Ultramarine Glacier. The Ultramarine samples were from $6 \mathrm{~km}$ southeast of the Nellie Juan study area and from a similar setting, and are included to increase sample size through the $\sim \mathrm{AD} 1600$ transition of subfossil to living trees in the chronology. Only series with 230 or more rings were included in the chronology; these longer series help preserve low-frequency (decadal to century) information (Cook and others, 1995).

Using routines in the ARSTAN program (personal communication from E. Cook, 2001), all series were power-transformed using the spread-vs-level method (Cook and Peters, 1997) and then detrended using conservative negative exponential curves, linear regression lines and flexible splines fitted to the data according to the $67 \% n$ criterion (Cook and Kairiukstis, 1990). Indices were calculated as residuals from the expected growth curve and combined into a final chronology using a biweight robust mean to reduce the influence of outliers. A running Expressed Population Signal was used to 
determine that the chronology has sufficient signal quality from $\mathrm{AD} 1150$ to the present for paleoclimatic interpretation.

Correlations were calculated between the Nellie Juan long chronology and monthly meteorological data from Seward, $67 \mathrm{~km}$ southwest of the study site, for the period 1908-90. Positive correlations significant at the 1\% level were found with average monthly temperatures in February, May and June, and a significant negative relationship was found with total precipitation in May (Fig. 4). The strongest relationship was found with mean monthly temperature range (difference of monthly maximum and minimum temperatures) in May, June and July; this temperature range will be greatest when cloudless conditions cause large diurnal temperature ranges and so is an index of solar radiation.

The smoothed Nellie Juan long tree-ring chronology shows three distinct intervals of reduced tree growth that correspond with the general intervals of glacier advance (Fig. 3). Each LIA glacial expansion continued while tree rings were below the long-term average, and ice retreat generally coincided with above-average tree growth. This correspondence, taken together with the correlation of ring widths with summer temperatures and radiation at Seward, supports interpretation of the Nellie Juan long tree-ringwidth chronology as a proxy of glacier melting.

Although the tree-ring data are from glacier forefields, cold air from the advancing ice margins is unlikely to be the cause of the reduced growth seen in the early, middle and late LIA. Bray and Struik (1963) have shown that significant growth suppression is restricted to within a few meters of an ice margin, and so the Nellie Juan tree-ring-width chronology primarily reflects regional climate.

\section{DISGUSSION}

The advance of Nellie Juan Glacier between 1539 and 1610 occurred at a time of generally declining tree growth (Fig. 3). While this suggests the advance may have been climatically driven, this is significantly earlier than the middle-LIA advances of nearby land-terminating glaciers. The alternative is that this stage of the advance compensated for the loss of ablation area during a presumed earlier retreat of Nellie Juan Glacier $>1000$ years ago.

Less equivocal is the cause of the arrival and stillstand of the tidewater terminus at the late-Holocene maximum from the 1840 s to $1890 \mathrm{~s}$. This coincides with a major reduction in summer temperatures and radiation that caused both reduced tree growth and advance of land-terminating glaciers throughout south central Alaska (Fig. 3). The limit of this advance is not at a significant widening or deepening of Derickson Bay, so this maximum was almost certainly controlled by climate rather than geometric factors (Mercer, 1961).

Retreat from the terminal moraine starting in the $1890 \mathrm{~s}$ was also most likely driven by a regional change in climate (Fig. 3). If iceberg calving rate determined by water depth is the primary control of unstable rapid retreat (Brown and others, 1982) then the gradual retreat of Nellie Juan Glacier from the proximal side of the terminal shoal after 1935 placed the tidewater margin in deeper water, resulting in faster calving and triggering rapid retreat. Alternatively, applying the height-above-buoyancy model (Van der Veen, 1996) would suggest that thinning of the terminal lobe of Nellie Juan Glacier by surface melting between the 1890s and 1930s was ultimately responsible for initiating rapid retreat.
Table 2. Timing of most recent major expansion of south central Alaskan tidewater glaciers. Glaciers are listed in geographical order from northeast to southwest. Dates are from direct observations and tree-ring methods unless otherwise noted

\begin{tabular}{lcc}
\hline Glacier & Duration of advance & Date of retreat \\
\hline Shoup $^{2}$ & Unknown & Unknown \\
Columbia $^{1}$ & $1057-1778$ & 1982 \\
Meares $^{2}$ & Advancing & - \\
Yale $^{2}$ & Before 1807 & 1827 \\
Harvard $^{2}$ & Advancing & - \\
Barry $^{3}$ & Unknown & 1884 \\
Surprise $^{2}$ & Unknown & $\sim 1880 \mathrm{~s}$ \\
Harriman $^{2}$ & Advancing & - \\
Blackstone $^{4}$ & Unknown & Before $1400^{6}$ \\
NellieJuan $^{6}$ & $1539-1842$ & 1893 \\
Chenega $^{2}$ & Unknown & 1882 \\
Tiger $^{2}$ & Unknown & Unknown \\
Aialik $^{5}$ & $\sim 1160^{6}$ & Before 1700 \\
Holgate $^{5}$ & Unknown & Unknown \\
Northwestern $^{5}$ & $1110^{6}-1490^{6}$ & 1894 \\
McCarty $^{5}$ & $\sim 570^{6}-1790$ & 1905 \\
& & \\
\hline
\end{tabular}

${ }^{1}$ Lapham (2001); ${ }^{2}$ Field (1975); ${ }^{3}$ Tarr and Martin (1914); ${ }^{4}$ Heusser (1983);

${ }^{5}$ Wiles and others (1995); ${ }^{6}$ Radiocarbon age.

Although retreat of Nellie Juan Glacier from the lateHolocene maximum was driven by climate, initiation of rapid iceberg-calving retreat did not occur until about 40 years later, when the terminus had completely retreated from the top of the terminal moraine shoal. Therefore, triggering of rapid iceberg-calving retreat was controlled by both the magnitude and duration of the climate change causing terminus recession, and the dimensions of the terminal moraine shoal. The shoal dimensions, in turn, depend on time, fjord geometry and the glacial sedimentary and hydrologic systems that deliver sediment to the terminus (Alley, 1991; Powell, 1991).

The climate changes in the late 19th century were also responsible for driving fluctuations of other tidewater glaciers in south central Alaska. Of the eight systems with well-constrained retreat dates from maxima, six began their retreats between the 1880s and 1905 (Table 2). Tangborn (1997) determined that the onset of rapid retreat of Columbia Glacier followed a sustained period of negative mass balance from 1949 to the early 1970 s; the tree-ring record of temperatures and 20th-century retreat of land-terminating glaciers suggests that this mass-balance deficit may have been ongoing since the 1890s. Three south central Alaskan tidewater glaciers are currently advancing, and the retreat of a further five from maxima is not adequately dated. This leaves only Yale Glacier as having an apparently anomalous timing of retreat. The retreat date of 1827 does coincide with a brief warming in the tree-ring record (Fig. 3), but this seems too short to have initiated retreat, especially when this warming had no apparent effect on the four tidewater glaciers known to have been at or near maxima at this time.

Initiation of retreat of tidewater glaciers from extended positions by non-climatic causes alone is certainly possible. For example, Post and Motyka (1995) suggest that outburst of an ice-dammed lake may have triggered retreat of Taku Glacier in 1750, and Alley (1991) outlines several possible ways in which sedimentary processes by themselves may cause terminus retreat. However, the record of south central Alaskan glaciers for the late Holocene suggests that such non-climatic triggering events are the exception rather than the rule. 


\section{CONGLUSIONS}

Tree-ring cross-dates from glacially killed and damaged trees show that the tidewater Nellie Juan Glacier advanced seawards during the 16 th and 17 th centuries, and stood at a late-Holocene maximum from the 1840s to 1890s. This maximum occurred during a regional reduction in summer temperatures and radiation when nearby land-terminating glaciers also reached maxima. The coherence with paleoclimatic forcing suggests that Nellie Juan Glacier was sensitive to climate while at this extended position.

The timing of retreat of Nellie Juan Glacier from the late-Holocene maximum was also at a significant change in climate that caused coeval retreat of land-terminating glaciers in the region. However, the onset of rapid icebergcalving retreat was delayed for about 40 years until the tidewater terminus of Nellie Juan had retreated from the terminal moraine shoal. Therefore, both the dimensions of this shoal and the magnitude and duration of the climate change that caused terminus recession were important to the initiation of rapid retreat.

\section{AGKNOWLEDGEMENTS}

This research was supported by the U.S. National Science Foundation under grant No. 9912124. D. Maraldo and J. Milligan assisted with fieldwork and with preliminary cross-dating of tree-ring samples. A. Post provided aerial photographs, and climate data were from the Alaskan Historical Climatology Network online at the Alaskan Climate Research Center (ftp://climate.gi.alaska.edu/). Reviews by N. Hulton, J. Jarvis and C. Warren helped improve the focus of this paper.

\section{REFERENGES}

Alley, R. B. 1991. Sedimentary processes may cause fluctuations of tidewater glaciers. Ann. Glaciol., 15, 119-124.

Barclay, D. J., G. C. Wiles and P. E. Calkin. 1999. A 1119-year tree-ring-width chronology from western Prince William Sound, southern Alaska. Holocene, 9(1), 79-84.

Bray, J. R. and G. J. Struik. 1963. Forest growth and glacial chronology in eastern British Columbia, and their relation to recent climatic trends. Can. F. Bot., 41(8), 1245-1271.

Brown, C. S., M. F. Meier and A. Post. 1982. Calving speed of Alaska tidewater glaciers with application to Columbia Glacier. U.S. Geol. Surv. Prof. Pap., 1285-C.

Cook, E. R. and L. A. Kairiukstis, eds.. 1990. Methods of dendrochronology: applications in the environmental sciences. Boston, MA, Kluwer Academic Publishers.
Cook, E. R. and K. Peters. 1997. Calculating unbiased tree-ring indices for the study of climatic and environmental change. Holocene, 7(3), 361-370.

Cook, E. R., K. R. Briffa, D. M. Meko, D. A. Graybill and G. Funkhouser. 1995. The "segment length curse" in long tree-ring chronology development for paleoclimatic studies. Holocene, 5 (2), 229-237.

Davidson, G. 1904. The glaciers of Alaska that are shown on Russian charts or mentioned in older narratives. Geogr. Soc. Pacific Trans. (San Francisco, CA), Ser. 2, 3.

Field, W. O., Jr. 1937. Observations on Alaskan coastal glaciers in 1935. Geogr. Rev., 27(1), 63-81.

Field, W. O. 1975. Mountain glaciers of the Northern Hemisphere. Atlas. Hanover, NH, U.S. Army Corps of Engineers. Cold Regions Research and Engineering Laboratory.

Grant, U. S. and D. F. Higgins. 1913. Coastal glaciers of Prince William Sound and the Kenai Peninsula, Alaska. U.S. Geol. Surv. Bull. 526.

Heusser, C. J. 1983. Holocene vegetation history of the Prince William Sound Region, south-central Alaska. Quat. Res., 19(3), 337-355.

Holmes, R. L. 1983. Computer-assisted quality control in tree-ring dating and measurement. Tree-Ring Bull., 43(1), 69-78.

Lapham, K. A. 2001. The past thousand years of glacial change from Columbia Glacier, Prince William Sound, Alaska. (B.Sc. thesis, College of Wooster, Wooster, $\mathrm{OH}$.)

Mann, D. H. 1986. Reliability of a fjord glacier's fluctuations for paleoclimatic reconstructions. Quat. Res., 25(1), 10-24.

Meier, M. F. and A. Post. 1987. Fast tidewater glaciers. 7. Geophys. Res., 92(B9), 9051-9058.

Mercer, J. H. 1961. The response of fjord glaciers to changes in the firn limit. 7. Glaciol., 3 (29), 850-858.

Post, A. 1975. Preliminary hydrography and historic terminal changes of Columbia Glacier, Alaska. U.S. Geol. Surv. Hydrol. Invest. Atlas HA-559, 3 maps (scale $1: 10,000$.)

Post, A. and R.J. Motyka. 1995. Taku and LeConte Glaciers, Alaska: calving-speed control of Late-Holocene asynchronous advances and retreats. Phys. Geogr., 16(1), 59-82.

Powell, R. D. 1991. Grounding-line systems as second-order controls on fluctuations of tidewater termini of temperate glaciers. In Anderson, J. B. and G. M. Ashley, eds. Glacial marine sedimentation; paleoclimatic significance. Boulder, CO, Geological Society of America, 75-93. (GSA Special Paper 261.)

Tangborn, W. 1997. Using low-altitude meteorologicalobservations to calculate the mass balance of Alaska's Columbia Glacier and relate it to calving and speed. Byrd Polar Res. Cent. Rep. 15, 142-161.

Tarr, R. S. and L. Martin. 1914. Alaskan glacier studies of the National Geographic Society in the Yakutat Bay, Prince William Sound and lower Copper River regions. Washington, DC, National Geographic Society.

Van der Veen, C. J. 1996. Tidewater calving. F. Glaciol., 42(141), 375-385

Viereck, L. A. 1967. Botanical dating of recent glacial activity in western North America. In Wright, H. E. and W. H. Osburn, eds. Arctic and alpine environments. Vol. 10. Bloomington, IN, Indiana University Press, 189-204.

Warren, C. R. 1991. Terminal environment, topographic control and fluctuations of West Greenland glaciers. Boreas, $20(1), 1-15$.

Wiles, G. C., P. E. Calkin and A. Post. 1995. Glacier fluctuations in the Kenai Fjords, Alaska, U.S.A.: an evaluation of controls on iceberg-calving glaciers. Arct. Alp. Res., 27(3), 234-245.

Wiles, G. C., D. J. Barclay and P. E. Calkin. 1999. Tree-ring-dated Little Ice Age histories of maritime glaciers from western Prince William Sound, Alaska. Holocene, 9(2), 163-173. 